\title{
The Habermasian Headache: A Response to Dieter Misgeld
}

\author{
Henry A. Giroux
}

Pennsylvania State University

Postmodernism seems to be eliciting one of two responses among its critics these days. On the one hand, there is the claim that it has gone the route of most theoretical fashions and is now relegated to the trash can of history. On the other hand, postmodernism (in its varied constructions) engenders in varying degrees of hostility a moralizing theoretical posture that suggests in its defensiveness that the very status of cultural criticism and the identity of the "critical" intellectual are being delegitimized and dangerously undermined. I think it is the latter response that provides a viable explanation to Misgeld's rather frantic attempt not only to criticize my theoretical engagements with postmodernism, but also to indict the very nature of the scholarship that informs the work I have done over the last few years. Misgeld's project here is not focused on critically engaging my view of postmodernism; he wishes to denigrate the foundation of my scholarly work so as to make it appear that I offer nothing valuable except to write, as he puts it, in a manner that is "characteristically grandiose" or "invites amusement at the naiveté and arrogance involved."

Difference appears as a dirty concept in Misgeld's vocabulary; it is scorned as a referent for postmodern cultural criticism and ignored as a basis for interrogating the politics of his own location. For example, Misgeld's use of the term amusement to denigrate my work has a certain haunting quality to it, one that places him inside rather than outside of the contextual politics and inquiries of the new cultural discourses of difference. Dare I ask: amusement as assumed by whom, enunciated from what particular location, and in whose interests? Misgeld is curiously silent on this issue and speaks in a voice strangely affiliated with the legacy of colonial authority, one that legitimizes itself through an act of enunciation that refuses to recognize the partial nature of his own location and form of address. How convenient the appeal to universals becomes in this case. Does the mere assertion of universals turn the object of one's criticism into a stranger? Is this a form of authoring within social criticism that merely reinvents modernism's colonial legacy on the high stage of academic discourse? 
Maybe this is why Misgeld can wave his ethereal orthodoxy without the slightest hint of self-reflection when he argues that postmodern educators "write like social theorists or philosophers, but do not expose themselves to the criticism of professionals in these fields. They write about pedagogy and as critical educators. But they are utterly unresponsive to the needs of day-to-day practice in concrete educational settings." What does it mean to suggest that I do not expose myself to other theorists in other fields? Has Misgeld done an inventory of where I have been published, given talks, debated with other theorists? And how does this somehow secure the charge that I am unresponsive to the day-to day practices of teachers? What does it mean to be unresponsive, in what contexts, and under what conditions? What are the needs to which Misgeld refers?

Unfortunately, the theoretical sweep of Misgeld's criticism is so broad and decontextualized as to become meaningless. He references a variety of my texts written at distinctly different historical and social conjunctions and in doing so ignores the theoretical and political conditions that gave them saliency; at the same time, he casually erases the differences among them. Moreover his sweeping generalizations are irresponsibly vague and betray a painfully shallow reading of my work. For example, I have never argued uncritically about postmodernism, and in Schooling and Democracy, Postmodern Education and Border Crossings I criticize a number of postmodern theorists for not addressing the issue of ethics and politics in their work. Moreover, I have never argued that postmodernism represents either the end of modernism or suggests a distinct break. On the contrary, I have repeatedly argued that postmodernism cannot be understood outside its relationship to modernism; that is, postmodernism posits itself less as a signal for the death of modernism than as a radical form of cultural criticism designed to negotiate, translate, and refigure the very nature of modernism's social, political, and cultural geography. ${ }^{1}$

Central to this challenge has been a renewed concern with issues of cultural translation, representation, and identity. In effect, I have argued that postmodernism must be taken seriously but not unproblematically. To claim that I have ignored fundamental challenges to postmodern discourses, while in fact referring to my essay, "Modernism, Postmodernism, and Feminism," suggests that Misgeld has either not read the essay carefully or is so incapable of taking seriously a position at odds with his own charges that he refuses to engage its basic arguments. In that essay I explicitly use a variety of feministpoststructuralist discourses to interrogate a number of postmodernism's defining assumptions. Moreover, I elaborate on my own criticisms regarding postmodernism and its relationship to issues of politics, ethics, historical inquiry, and agency. 
A similar ideological slip can be seen in Misgeld's characterization of John Searle's derogatory dismissal of radical theorists on the cultural left as "a well considered liberal position." This apparent misreading of Searle's outspoken conservatism on cultural issues is less important than Misgeld's refusal to acknowledge the relationship between his own politics and the critiques of reason, universalist, authorship, agency, and individuality that postmodern critics have subjected to rigorous attack.

As a marker for Misgeld's own position, it appears sufficient to dismiss my work as a kind of "hyperradicalism." But it is precisely this type of polarizing language that structures many of the arguments that Misgeld constructs to buttress his own political position. Within such binarisms, it is not difficult to figure out who is on the side of the angels. Misgeld's cautionary tale about radicals promising more than they can deliver and hence his own call to pursuing less radical goals places him squarely in the liberal camp he seems to both love and despise.

Misgeld points out a number of concerns that critical educators should address. Might there be any disagreement on these concerns, are there other concerns, other problematics, different voices to be heard, a different sense of what matters politically and what does not? Not for Misgeld. He posits an unproblematic line of inquiry and then condemns me for not taking it up seriously. It is precisely this type of theoretical orthodoxy, with its authoritarian refusal to recognize the contested and partial character of one's own position, that makes Misgeld's appeal to self-enlightenment and critical communication seem empty. Moreover, it is just this kind of theoretical scaffolding that feminist theorists and various postmodern theorists have been opposing for years. The tensions within schools should be explored, but the specific tensions to be named, addressed, and transformed do not always come, as Misgeld presupposes, in such neat theoretical and political packages. Questions concerning how social identities are fashioned, how cultural domination is secured, how different social groups struggle under different forms of inequality, and how social agency manifests itself in both dominating and emancipatory terms in different contexts are serious concerns to a number of theorists who are too often dismissed in the kind of sweeping claims that seem to inform Misgeld's own position.

What is one to make of Misgeld swimming around in the heady clouds of universalized reason while condemning those of us criticizing essentialism for not embracing his Habermasian fixation on universalism? ${ }^{2}$ According to Misgeld, my rejection of universalism will promote despair, chaos, and irresponsibility. But I have addressed these same arguments in my analysis (with Stanley Aronowitz) of Allan Bloom's position, a position that has curious intersections with Misgeld's. Per- 
haps Misgeld refused to read that chapter or the various works in which I take up the issue of universalism, essentialism, politics, and agency. What is one to make of the charge that I falsely make liberalism compatible with the alternative projects of democracy? Is Misgeld suggesting that there is nothing in liberalism that can be appropriated critically as part of a refusal to embrace either the tenets of Civic Republicanism or Liberalism? I do not attempt to make these traditions compatible as much as I attempt to create a third space for alternative conceptions of radical democratic politics by appropriating critically different elements of both liberalism and democratic pluralist traditions, among others. But Misgeld misses this and construes an illegitimate opposition between two extreme alternatives. Trapped in his suffocating polarities, Misgeld can only pit one paradigm against the other, hence the refusal to either recognize or engage the attempt in my work to develop a vocabulary that aims to negotiate and translate these discourses within a postmodern democratic project. Maybe it is the fatal character of constructing such binarisms that allows Misgeld to characterize my work as exhibiting an enormous "lack of discrimination." Yet at the same time, it appears that it is precisely his disregard for such discrimination that prompts him to claim unproblematically that my work should be dismissed because it ignores a universal set of principles against which my understanding and engagement with various educational practices could then be measured.

Perhaps, it is not so indiscriminate to interrogate the pompous assumption that there is only one master narrative that can adequately elucidate how culture operates as an active agent in the production of places, spaces, and social relations marked by the intersecting practices of containment and possibility. In spite of Misgeld's charge of "great self-indulgence" I would argue that Misgeld arrogantly assumes my work is of no value to teachers. How can he argue without being ironic that I am not "in a position to give much support to teachers who are faced with the relevant practical dilemmas and challenges." What teachers? Are they all the same? Has he investigated how my work is taken up by different cultural workers and teachers in the United States, Canada, or Latin America? Does he speak for all teachers? Hardly, a humble position, but clearly this is one that speaks less to my own acts of "self-indulgence" than it does to Misgeld's refusal to recognize the privileges and limitations of the theoretical and political locations from which he speaks. I suggest that in the future he defend his own sense of ethereal agency rather than assume the task of speaking for all those teachers whom he assumes think just as he does.

For all of his ravings about the "normative" sense that is missing from my work, I strongly suggest that he read Schooling and Democracy, and a number of other articles in which I have addressed the related 
issues of ethics, authority, and the responsibility of teachers as public intellectuals. Moreover, the thrust of my concern about postmodernism has never collapsed into an uncritical acceptance of its basic tenets (as if there were no contradictory discourses involved here). In fact, I have always engaged postmodernism as a form of cultural criticism to be interrogated as part of a larger effort to extend and deepen the project of radical democracy and the place of schools and other forms of cultural work within it. Misgeld appears to have a Habermasian hangover. Does criticizing Habermas' view of modernism and his critique of postmodernism automatically mean that one has not read him seriously? Does criticizing specific features of modernism from certain postmodernist perspectives mean that all the progressive features of modernism have come to an end? This is certainly not my position; rather, it is one that I have argued against vigorously in three of the books that Misgeld cites. Misgeld appears to be trapped in a narrative sutured in a view of reason so totalizing that it negates his ability to reflect on the assumptions that inform both his own theoretical location and the strengths and limitations of those discourses that such a view is so quick to dismiss as either unscholarly, self-indulgent, or simply not clear.

One wonders, what does Misgeld have to offer critical educational theory and practice with this kind of shrill, feckless critique? One source of Misgeld's acrimonious assault is my appropriation of theoretical work that does not celebrate his own characterizations of certain thinkers such as Theodor Adorno and Walter Benjamin. Does this suggest a misreading on my part or simply point to a position at odds with Misgeld's? Contrary to what Misgeld believes, I support the recent observation made by Steven Best and Douglas Kellner, who claim that Adorno "constituted a critique of philosophy quite similar to that later developed by postmodern theory" (Best \& Kellner, 1991). Moreover, Benjamin's work has highly influenced postmodern art critics such as Abigail Solomon-Godeau, John Tagg, and numerous others. ${ }^{3}$ Theoretical traditions and paradigms are neither unified, transparent, nor self-sustaining. In spite of Misgeld's intransigence, such positions are contradictory and open to debate; moreover, the notion that such paradigms must retain an ideological purity before they can be appropriated is itself a highly problematic and in my mind a deeply flawed position. Positions of certainty may allow one to occupy the academic high ground but in doing so it offers little room for productive dialogue about issues of textual authority, politics, representation, and power.

Misgeld's position has less to do with a spirited defense of political modernism than it does with a weak defense of liberalism. Further, Misgeld's appeal to clarity, self-enlightenment, and communication seems to be canceled out in his strikingly conservative implication that radical educators often confuse politics and education with indoctrina- 
tion. While I would not accuse Misgeld of red baiting, it is precisely this argument that conservatives and liberals have used consistently in the United States to depoliticize radical pedagogy while not addressing its substantive criticisms. Misgeld's charge is certainly not characteristic of my work, nor is it characteristic of the diversity found in the work of many postmodernists, feminists, and others who write from a radical educational perspective. If anything, Misgeld's charge is characteristic of the conservative attempt in the United States to stifle critical work by simply dismissing it as politically incorrect.

What is needed by critical theorists is a serious, sustained, and close reading of the content and contexts of the texts singled out for analysis. Clearly, this is an approach far removed from Misgeld's. Instead, he appears, given his reckless generalizations, and snide asides, to simply mine the texts under investigation for self-serving, decontextualized assertions in order to sustain his foregone conclusions. You would think Misgeld might have wanted to give his readers some sense of what his own theoretical/political location is and how it translates into a strategy for change. Instead, in the all too predictable move of the logocentric intellectual, he ends up appealing to textual accessibility and pinning his hopes on the virtues of critical thinking and communicative competence, while at the same time disclaiming education as a political act. Misgeld's project is not designed to address and transform the problems of schooling in North America; it is neo-liberalism touting the virtues of its own normative ideological agenda. If Misgeld has achieved anything worthwhile in his rather self-serving critique, it is to make clear the degree to which the defenders of modernism need to be critically engaged.

\section{Notes}

1. More is at stake here than postmodernism's relation to modernism. Misgeld's treatment of postmodernism as a unified discourse, his reductionistic refusal to engage the diverse educational theorists (particularly feminists) who have aligned themselves with various forms of postmodern criticism, and his treatment of critical pedagogy as a unified tradition represents nothing less than a massive reification of these terms. None of these categories represent a coherent theoretical approach, can be sustained by a unified definition, or can be addressed outside of the intersecting theoretical and political differences that define them.

I have addressed this issue of the relationship between modernism and postmodernism in Aronowitz and Jenks (1991).

2. For a brilliant critique of Enlightenment universalist, see Scott's (1992a) and Mouffe's (1992a) analyses of the modernist construction of experience and identity. Scott attempts to show how this position promotes a conservative politics in "the name of an unquestioned and unquestionable tradition, universality, or history" ( $p$. 12). Mouffe, on the other hand, attempts to show how an anti-essentialist position can further what she calls a radical democratic project. Both of these positions are at odds with Misgeld's theoretical project and offer a sustained critique of it and its many representations (also see Scott, 1992b). Some of Mouffe's recent writings on this issue can be found in Mouffe (1992a; 1992b). Misgeld's theoretical sloppiness 
regarding postmodernism is similar in context and content to the work of David Harvey. For a critique of this view of postmodernism, see Morris (1992).

3. All of these authors critically engage and appropriate aspects of Benjamin's work. See Solomon-Godeau (1991); Tagg (1992). Solomon-Godeau argues that critics such as Benjamin theorized those aspects of post modernist photographic work in "its dismantling of reified, idealist conceptions enshrined in modernist aesthetics-issues devolving on presence, subjectivity, and aura" (p. 127).

\section{References}

Aronowitz, S., \& Jenks, H.A. (1991). Postmodernism and the discourse of educational criticism. In Postmodern Education (pp. 57-86). Minneapolis: University of Minnesota Press.

Best, S., \& Kellner, D. (1991). Postmodern theory: Critical interrogations. New York: Guilford Press.

Mouffe, C. (1992a). Feminism, citizenship, and radical democratic politics. In J. Butler \& J.W. Scott (Eds.), Feminists theorize the political (pp. 369-384). New York: Routledge.

Mouffe, C. (1992b). Citizenship and political identity. October, 61, 28-32.

Morris, M. (1992). The man in the mirror: David Harvey's condition of postmodernity. Theory, Culture, and Society 9(1), 253-279.

Scott, J.W. (1992a). Experience. In J. Butler \& J.W. Scott (Eds.), Feminists theorize the political (pp. 22-40). New York: Routledge.

Scott, J.W. (1992b). Multiculturalism and the politics of identity. October, 61, 12-19.

Solomon-Godeau, A. (1991). Photography at the dock: Essays on photograhic Hester institutions, and practices. Minneapolis: University of Minnesota Press.

Tagg, J. (1992). Grounds of dispute: Art history cultural politics and the discursive field. Minneapolis: University of Minnesota Press. 